\title{
Efektivitas karet alam termoplastik sebagai peningkat indeks viskositas minyak pelumas kendaraan
}

\section{Effectivity of thermoplastic natural rubber as viscosity index improver of automotive lubricating oil}

\author{
Santi Puspitasari ${ }^{1, *}$, Muhammad Lutfi Arifianto ${ }^{2}$, Mersi Kurniati ${ }^{2}$ \\ ${ }^{1}$ Pusat Penelitian Karet, Jalan Salak Nomor 1, Bogor 16151, Indonesia \\ ${ }^{2}$ Departemen Fisika, Institut Pertanian Bogor, Kampus IPB Darmaga Bogor, Indonesia \\ *Penulis korepondensi. Telp.: +62 251 8319817; Fax.: +62 2518324047 \\ E-mail: puspitasari.santi@puslitkaret.co.id
}

Diterima: 7 April 2016 Direvisi: 12 Mei 2016 Disetujui: 20 Mei 2016

\begin{abstract}
Diversification of rubber goods are highly needed to enhance natural rubber domestic consumption. One of the efforts is by using thermoplastic natural rubber that is synthesized from emulsion graft copolymerization of natural rubber latex with thermoplastic monomer as index viscosity improver of lubricating oil. The research aimed to study the effect of thermoplastic natural rubber (natural rubber-styrene copolymer) addition, at various concentration, into base paraffinic lube oil (HVI 60 and HVI 650) on index viscosity value of lubricating oil. The result showed that emulsion graft copolymerization at composition ratio of natural rubber to styrene monomer $85: 15$, at $65^{\circ} \mathrm{C}$ for 7 hours, with addition of $1 \%$ ammonium peroxidisulfate as initiator and $2 \%$ sodium dodecyl sulfate as surfactant produced thermoplastic natural rubber (TPNR, copoly NR-ST) with grafting efficiency of $56,48 \%$. The TPNR can be functioned properly as index viscosity improver at 5\% concentration to base paraffinic lube oil either HVI 60 or HVI 650. The obtaining new lubricating oils could fulfill the index viscosity standard requirement refered to Decree of Directorat General of Oil and Gas No 85K/34/DDJM/1998, and could compete with the commercial lubricating oil type $20 \mathrm{~W}-50,10 \mathrm{~W}-40$, and $15 \mathrm{~W}-40$.
\end{abstract}

Keywords: thermoplastic natural rubber, lubricating oil, index viscosity improver, graft copolymerization, styrene monomer.

\section{ABSTRAK}

Diversifikasi barang jadi karet alam sangat diperlukan untuk mendukung peningkatan konsumsi domestik produksi karet alam nasional. Salah satu upaya yang dapat dilakukan adalah dengan memanfaatkan karet alam termoplastik hasil kopolimerisasi cangkok emulsi lateks karet alam dengan monomer termoplastik sebagai bahan aditif jenis peningkat indeks viskositas minyak pelumas. Penelitian ini dimaksudkan untuk mempelajari pengaruh penambahan berbagai dosis karet alam termoplastik (kopolimer dari karet alam - stirena) ke dalam minyak lumas dasar golongan parafinik HVI 60 dan HVI 650 terhadap nilai indeks viskositas minyak pelumas baru. Hasil penelitian menunjukkan bahwa reaksi kopolimerisasi cangkok emulsi yang dijalankan pada rasio karet alam terhadap monomer stirena sebesar $85: 15$, pada suhu $65^{\circ} \mathrm{C}$ selama $7 \mathrm{jam}$, dengan penambahan $1 \%$ insiator amonium peroksidisulfat dan $2 \%$ surfaktan sodium dodesil sulfat mampu menghasilkan karet alam termoplastik (TPNR, kopoli NR-ST) dengan efisiensi cangkok 56,48\%. Pada dosis 5\% TPNR terhadap minyak lumas dasar berfungsi dengan baik sebagai peningkat indeks viskositas karena memenuhi persyaratan indeks viskositas standar sesuai Surat Keputusan Ditjen Migas Nomor 85K/34/DDJM/1998, dan dapat bersaing dengan minyak pelumas komersial tipe 20W-50, 10W-40 dan 15W-40.

Kata kunci: karet alam termoplastik, minyak lumas, peningkat indeks viskositas, kopolimerisasi cangkok, monomer stirena. 


\section{PENDAHULUAN}

Konsumsi domestik karet alam mentah lebih rendah dibandingkan kebutuhannya untuk memenuhi permintaan ekspor. Menurut data statistik, industri barang jadi karet nasional hanya mampu menyerap sekitar $18 \%$ dari total produksi karet alam mentah di dalam negeri yang didominasi oleh industri ban kendaraan (tyre industry). Penambahan diversifikasi jenis barang jadi karet merupakan salah satu upaya yang dapat dilakukan untuk meningkatkan nilai ekonomi dan daya guna karet alam. Industri sarana prasarana transportasi di luar industri ban kendaraan turut memegang peluang besar dalam penyerapan karet alam misal untuk pembuatan suku cadang otomotif dan komponen kendaraan, penanda marka jalan, aspal termodifikasi polimer (aspal karet) bahkan hingga sebagai aditif dalam industri minyak pelumas (lubricating oil). Kebutuhan minyak pelumas sebanding dengan jumlah kendaraan, berdasarkan data Badan Pusat Statistik (2016), pada tahun 2013 jumlah kendaraan bermotor di Indonesia mencapai 104,1 juta unit dengan rincian roda empat sebanyak 19,4 juta unit dan roda dua sekitar 84,7 juta unit. Effendi dan Adawiyah (2014), merekomendasikan penggantian minyak pelumas berdasarkan pemakaian setelah jarak tempuh sejauh $5.000 \mathrm{~km}, 10.000 \mathrm{~km}$ hingga $20.000 \mathrm{~km}$. Apabila diasumsikan setiap kendaraan per tahun memerlukan 8 liter minyak pelumas/ unit roda empat dan dua liter minyak pelumas/ unit roda dua untuk perawatan kendaraan maka kebutuhan minyak pelumas mencapai 325 ribu kiloliter/tahun.

Minyak pelumas merupakan suatu zat cair yang ditempatkan sebagai perantara antara dua benda yang saling bergerak untuk meminimalisir terjadinya gesekan antara kedua benda tersebut sehingga tingkat keausan logam, dan tingkat kerusakan mesin dapat dikurangi (Nugroho \& Sunarno, 2012). Minyak pelumas diproduksi dari minyak lumas dasar (mineral base oil) baik tanpa maupun dengan penambahan jenis dan dosis bahan aditif sesuai perangkat mesin dan karakteristik akhir minyak pelumas yang diinginkan (Suhartini dkk., 2006). Aditif dapat memberikan sifat baru atau memperbaiki sifat dari minyak lumas dasar (Abdel-Azim \& Abdel-Aziem, 2001; Ahmed \& Nassar, 2011). Jenis bahan aditif minyak pelumas dipilih berdasarkan fungsinya antara lain anti oksidan, bahan pelindung korosi, bahan anti busa, bahan pembersih serta pengurai (Adriany
\& Yuliarita, 2009). Penambahan bahan aditif pada minyak lumas dasar untuk minyak pelumas sistem hidrolik sebesar 2-10\%, gears (worm) $3-10 \%$, gears (spiral, bevel) 1-10\%, kompresor $0,5-5 \%$, dan mesin $10-30 \%$. Bahan aditif untuk kebutuhan industri minyak pelumas lokal masih harus dipenuhi secara impor.

Kinerja minyak pelumas turut ditentukan oleh kondisi lingkungan di sekitar mesin. Perubahan suhu operasi mesin akan diikuti oleh perubahan viskositas minyak pelumas. Apabila mesin beroperasi pada suhu tinggi maka viskositas minyak pelumas akan turun sehingga tidak dapat melindungi mesin dengan baik. Sebaliknya jika mesin dioperasikan pada suhu rendah maka viskositas minyak akan naik akibatnya suplai arus listrik menjadi tidak lancar sehingga mesin sulit menyala (Suhartini \& Rahmawati, 2009). Oleh karena itu agar dapat berfungsi secara optimal, minyak pelumas harus mampu bekerja pada jangkauan suhu yang luas (Suhartini \& Rahmawati, 2010). Supaya minyak pelumas dapat tetap mempertahankan viskositasnya terhadap perubahan suhu, maka ketika pembuatan minyak pelumas, minyak lumas dasar yang digunakan ditambah dengan bahan aditif jenis peningkat indeks viskositas (viscosity index improver) (Almeida et al., 2014). Bahan peningkat indeks viskositas umumnya berupa polimer yang memiliki bobot molekul tinggi seperti polimetakrilat, poliakilmetakrilat, poliolefin, polidiena, polistirena yang dialkilasi dan poliester (Jukic et al., 2007; Adriany \& Yuliarita, 2009). Meskipun ditambahkan dalam konsentrasi yang cukup rendah, polimer akan sangat mempengaruhi reologi terutama viskositas dan indeks viskositas minyak pelumas (Sklepić et al., 2008). Selain kekentalan, indeks viskositas yang menyatakan fungsi viskositas minyak pelumas terhadap suhu menjadi tolak ukur dalam menentukan mutu minyak pelumas (Morgan et al., 2010). Nilai indeks viskositas diperoleh dengan cara membandingkan viskositas kinematik minyak pelumas pada suhu $40^{\circ} \mathrm{C}$ dan $100^{\circ} \mathrm{C}(\mathrm{Co}-$ vitch \& Trickett, 2015).

Karet alam dari klon Hevea brasiliensis merupakan polimer alami yang tersusun atas monomer isoprena membentuk konfigurasi cis1,4 poliisoprena yang mengandung ikatan rangkap $\mathrm{C}=\mathrm{C}$. Ikatan rangkap $\mathrm{C}=\mathrm{C}$ tersebut menyebabkan karet alam tidak tahan terhadap oksidasi namun karena sifatnya yang reaktif menjadikan karet alam mudah dimodifikasi secara kimiawi 
misal secara kopolimerisasi cangkok emulsi (Oliveira et al., 2005; Hinchiranan et al., 2009). Kopolimerisasi cangkok karet alam dengan monomer termoplastik menghasilkan karet alam termoplastik (thermoplastic natural rubber, TPNR) yang memiliki struktur rantai utama dari molekul karet alam dengan rantai cabang yang berasal dari monomer termoplastik yang saling berikatan secara kovalen (Arayapranee et al., 2002). Karakteristik TPNR sangat bergantung pada rasio komposisi karet alam terhadap monomer termoplastik, jenis monomer termoplastik, jenis dan dosis inisiator dan surfaktan, suhu serta waktu reaksi. Man et al. (2008) menjelaskan bahwa monomer stirena dan metil metakrilat dapat memberikan efisiensi kopolimerisasi yang tinggi.

Kopolimerisasi cangkok emulsi lateks karet alam dengan monomer stirena yang terjadi di dalam misel hasil asosiasi molekul surfaktan SDS berjalan dengan mekanisme adisi yang meliputi tiga tahapan reaksi yaitu inisiasi, propagasi,

Tahap Inisiasi

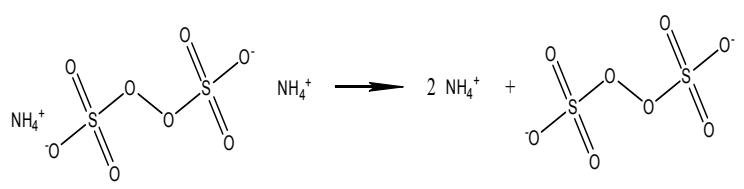

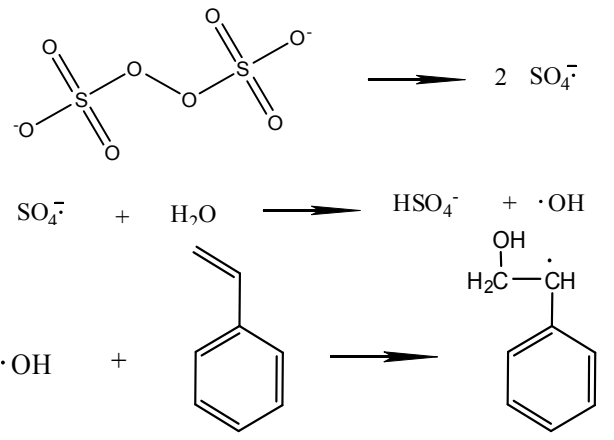

dan terminasi (Man et al., 2007; Yamak, 2013). Secara terperinci, mekanisme kopolimerisasi cangkok emulsi disajikan dalam Gambar 1. Tahap inisiasi merupakan tahap pembentukan radikal bebas persulfat $\left(2 \mathrm{SO}_{4}^{-}\right)$akibat dekomposisi inisiator amonium peroksidisulfat (APS) oleh pengaruh panas karena reaksi kopolimerisasi cangkok pembentukan karet alam termoplastik yang dijalankan pada suhu $65^{\circ} \mathrm{C}$. APS termasuk dalam kelompok inisiator termal golongan persulfat yang sering digunakan dalam reaksi kopolimerisasi cangkok emulsi lateks karet alam selain inisatior kalium persulfat (Puspitasari dkk., 2015). Selanjutnya pada tahap propagasi terjadi penyerangan radikal bebas persulfat terhadap molekul karet alam dan monomer stirena sehingga membentuk radikal molekul karet alam dan radikal monomer stirena. Pada tahap propagasi juga terjadi penggabungan antara radikal molekul karet dengan monomer stirena menghasilkan radikal kopolimer karet alam dan stirena (kopoli NR-ST),

Tahap Prograsi<smiles>CCC=C(C)CCCCCCCCCCC(C)C</smiles><smiles>C=Cc1ccccc1</smiles><smiles>CCC1Cc2ccccc2C(CC)c2ccccc21</smiles>

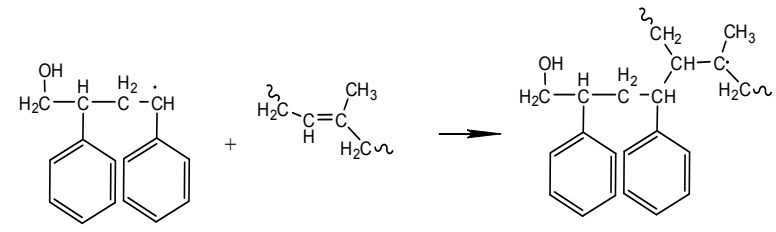

Tahap Terminasi
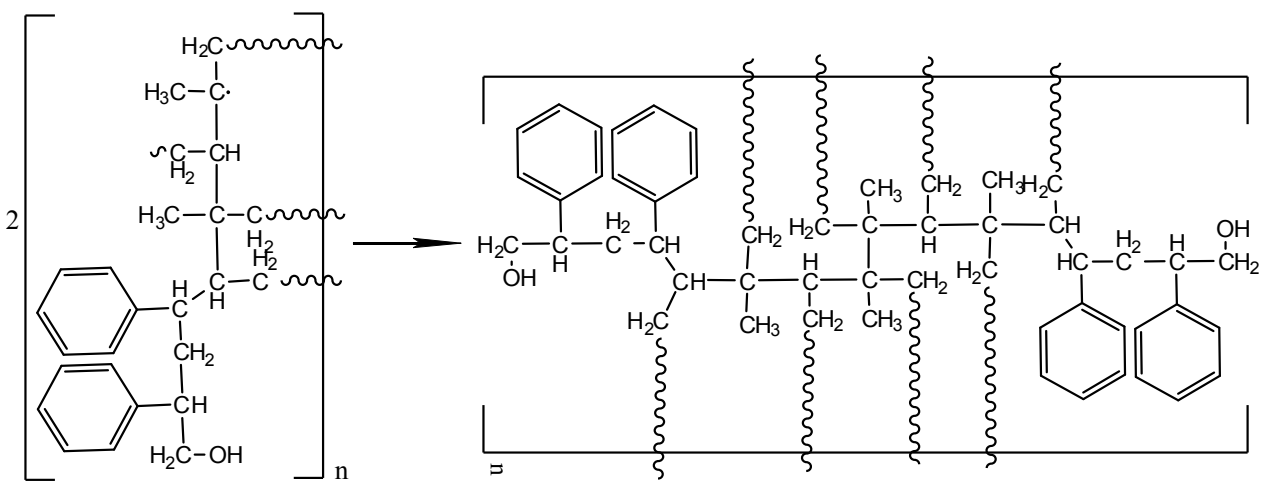

Gambar 1. Mekanisme kopolimeriasi cangkok emulsi pembentukan kopoli NR-ST. 
radikal monomer stirena dengan molekul karet yang juga membentuk radikal kopolimer karet alam-stirena, serta antar radikal stirena dengan molekul stirena menghasilkan radikal homopolistirena dengan rantai molekul yang lebih panjang. Reaksi kopolimerisasi cangkok termoplastik vinil seperti monomer stirena dalam lateks karet alam selalu disertai dengan reaksi homopolimerisasi pembentukan homopolimer stirena akibat sifat monomer stirena yang sangat reaktif (Songsing et al., 2013; Kohjiya \& Ikeda, 2014). Pada tahap akhir yaitu terminasi, terjadi penggabungan antar radikal kopolimer membentuk kopoli NR-ST atau antar radikal stirena membentuk homopolistirena.

TPNR yang terbentuk dari hasil perpaduan karet alam dengan stirena juga memiliki ketahanan terhadap oksidasi karena telah teradisinya ikatan $\mathrm{C}=\mathrm{C}$ dalam karet alam oleh monomer termoplastik serta memiliki kestabilan panas yang baik selain bobot molekul yang lebih besar daripada karet alam murni (Puspitasari, 2015). Bobot molekul yang tinggi pada TPNR disebabkan karena terjadinya pembentukan cabang monomer termoplastik pada rantai utama molekul karet alam tanpa disertai dengan pemutusan rantai molekul karet alam tersebut akibatnya karet alam dapat tetap mempertahankan sifat instrinsiknya sekaligus memiliki sifat unggul baru yang berasal dari monomer termoplastik yang terikat pada rantai molekul karet alam tersebut (Wei et al., 2014). Dengan demikian, TPNR dianggap berpeluang digunakan sebagai bahan peningkat indeks viskositas minyak pelumas untuk mesin kendaraan. Dengan asumsi penambahan bahan aditif peningkat indeks viskositas sebesar 3\% maka diperkirakan TPNR berpeluang dapat mensubsitusi bahan peningkat indeks viskositas impor sebesar sembilan ribu ton per tahun.

Penelitian ini bertujuan mempelajari pengaruh penambahan berbagai dosis TPNR yang diperoleh dari hasil modifikasi karet alam fase lateks secara kopolimerisasi cangkok emulsi dengan monomer stirena terhadap peningkatan indeks viskositas minyak lumas dasar jenis parafinik.

\section{BAHAN DAN METODE \\ Bahan Penelitian}

Bahan yang digunakan dalam penelitian terdiri atas lateks karet alam pekat kadar amonia tinggi (commercial high ammoniated latex concentrated, kadar karet kering 60\%) diperoleh dari
Kopkar INIRO, Pusat Penelitian Karet, Bogor. Bahan lainnya terdiri atas monomer termoplastik jenis stirena (kemurnian $\approx 98 \%$ ) diperoleh dari Sigma Aldrich, Singapura, inisiator APS (kemurnian $\approx 98 \%$ ), surfaktan sodium dodesil sulfat (SDS, kemurnian $\approx 98 \%$ ), dan pelarut $p$-silena diperoleh dari Merck, Jerman, serta metanol, aseton dan asam format spesifikasi teknis diperoleh dari CV. Setia Guna, Bogor. Selanjutnya minyak lumas dasar golongan parafinik High Viscosity Index HVI-60 dan HVI-650 diperoleh dari PT. Pertamina Lubricants, Jakarta.

\section{Peralatan Penelitian}

Peralatan yang digunakan dalam pembuatan karet alam termoplastik meliputi reaktor labu leher tiga yang dilengkapi dengan kondenser balik, termometer, dan labu tetes monomer. Sistem pemanasan dan pengadukan dalam reaktor dibangkitkan dari hot plate magnetic stirrer dengan pengaduk keramik dan penangas air sebagai media pemanas, mesin giling karet (crepper dan open mill), serta oven merek Memmert. Sedangkan dalam pembuatan minyak pelumas menggunakan gelas piala berukuran $1000 \mathrm{~mL}$ dan pengaduk mekanis. Instrumen pengujian untuk karakterisasi meliputi viskometer Brookfield dan spektrofotometer Fourier Transform Infra Red (FTIR) merek Nicolet i5 dari Thermoscientific yang dilakukan di Laboratorium Penguji Pusat Penelitian Karet, Bogor dan Atomic Absorption Spectrophotometer (AAS) yang dilakukan di Laboratorium Bahan, Departemen Fisika, Institut Pertanian Bogor, Bogor.

\section{Metode Penelitian}

Metode penelitian dibagi menjadi dua tahapan yaitu persiapan pembuatan karet alam termoplastik secara kopolimerisasi cangkok emulsi karet alam fase lateks dengan monomer termoplastik jenis stirena, kemudian dilanjutkan dengan pembuatan minyak pelumas dengan cara penambahan karet alam termoplastik ke dalam minyak lumas dasar golongan parafinik.

\section{Persiapan pembuatan karet alam termoplas-} tik

Dalam pembuatan karet alam termoplastik secara kopolimerisasi cangkok emulsi melalui teknik reaksi secara semi kontinyu mengikuti alur sebagai berikut: lateks karet alam pekat (kadar karet kering 60\%) dituangkan ke dalam reaktor, selanjutnya lateks karet alam diencerkan 
dengan menambahkan aquades hingga kadar karet kering lateks menjadi 15\%. Lateks encer dipanaskan secara bertahap hingga suhu lateks mencapai suhu reaksi. Ketika suhu $60^{\circ} \mathrm{C}$, ke dalam lateks ditambahkan surfaktan SDS sebanyak 2\% terhadap total bobot lateks dan monomer stirena. Selanjutnya ketika suhu reaksi mencapai $65^{\circ} \mathrm{C}$, secara berurutan ditambah dengan inisiator APS sebanyak $1 \%$ terhadap bobot total campuran dan monomer stirena setetes demi setetes. Rasio karet alam terhadap monomer stirena diatur sebesar 85:15. Reaksi kopolimerisasi cangkok dijalankan selama 7 jam dihitung dari tetes awal penambahan monomer stirena. Lateks karet alam termoplastik (kopolimer) yang diperoleh digumpalkan dengan larutan asam format 5\%. Gumpalan karet alam termoplastik kemudian digiling dalam mesin crepper sehingga menjadi lembaran (krep) basah karet alam termoplastik. Krep basah direndam dalam aseton selama 24 jam agar homopolimer stirena terpisah ditandai dengan terbentuknya endapan putih ketika ditetesi dengan metanol. Krep basah yang telah dimurnikan selanjutnya dicuci atau dibilas dengan air mengalir sebelum dikeringkan dalam oven pada suhu $50^{\circ} \mathrm{C}$ selama 48 jam.

\section{Pembuatan minyak pelumas}

Krep kering karet alam termoplastik murni (telah dieliminasi kandungan homopolimer stirenanya) yang akan diujicobakan sebagai peningkat indeks viskositas minyak pelumas digiling atau dimastikasi dalam open mill selama 15 menit. Krep karet alam termoplastik termastikasi kemudian dipotong-potong supaya berukuran lebih kecil sebelum dilarutkan dalam $p$-silena pada konsentrasi $20 \%$ pada suhu $60^{\circ} \mathrm{C}$. Larutan krep karet alam termoplastik 20\% dalam $p$-silena disebut dengan larutan induk. Karet alam termoplastik dalam larutan induk ditambahkan ke dalam minyak pelumas dasar (HVI 60 dan HVI 650 ) pada dosis $1 \%, 3 \%$, dan $5 \%$ pada suhu $50^{\circ} \mathrm{C}$. Minyak pelumas baru selanjutnya dikarakterisasi sifat fisika dan kimianya antara lain viskositas kinematik, densitas, indeks viskositas, kadar logam $\mathrm{Mg}$, kadar abu, dan $\mathrm{pH}$.

Penentuan indeks viskositas minyak pelumas berdasarkan metode dalam ASTM D2270 mengacu pada nilai viskositas kinematik pada suhu $40^{\circ} \mathrm{C}$ dan $100^{\circ} \mathrm{C}$. Nilai viskositas kinematik merupakan hasil pembagian antara viskositas dinamik dengan specific gravity minyak pelumas. Sedangkan viskositas dinamik minyak pelumas ditentukan dengan pengujian menggunakan viskometer Brookfield. Karakteristik minyak pelumas baru terbaik ditetapkan sebagai dasar dalam menentukan dosis optimum karet alam termoplastik yang digunakan sebagai peningkat indeks viskositas minyak pelumas.

\section{HASIL DAN PEMBAHASAN \\ Reaksi Kopolimerisasi Cangkok Pembentukan TPNR}

Keberhasilan reaksi kopolimerisasi cangkok karet alam dan monomer stirena ditentukan berdasarkan nilai efisiensi cangkok yang dihitung dengan membandingkan bobot monomer stirena tercangkok terhadap bobot monomer stirena awal. Bobot monomer stirena tercangkok merupakan selisih antara bobot monomer stirena awal dengan bobot homopolimer stirena yang terekstrak oleh aseton. Menurut hasil perhitungan diperoleh nilai efisiensi cangkok yang rendah hanya sebesar $56,48 \%$. Perhitungan efisiensi cangkok ditunjukkan pada Tabel 1.

Efisiensi cangkok yang rendah disebabkan oleh beberapa faktor penghambat reaksi kopolimerisasi cangkok emulsi karet alam dengan monomer stirena yaitu:

a. Karet alam yang digunakan sebagai bahan baku merupakan karet alam murni yang tidak dikurangi kandungan proteinnya secara deproteinisasi sehingga kadar proteinnya masih cukup tinggi. Dalam lateks karet alam segar dengan kadar karet kering sekitar 30-35\%

Tabel 1. Efisiensi cangkok pembentukan TPNR (kopoli NR-ST).

\begin{tabular}{lc}
\hline \multicolumn{1}{c}{ Parameter } & Jumlah \\
\hline Bobot karet alam, gram & 29,30 \\
Bobot monomer stirena, gram & 10,34 \\
Bobot total karet dan monomer stirena, gram & 39,64 \\
Bobot akhir TPNR setelah pemurnian, gram & 35,14 \\
Bobot homopolimer stirena terekstrak oleh aseton, gram & 4,50 \\
Efisiensi cangkok, \% & 56,48 \\
\hline
\end{tabular}


umumnya mengandung protein sebesar 2,2\% (Sakdapipanich \& Rojruthai, 2012). Keberadaan lapisan protein yang menyelubungi partikel karet alam mengakibatkan monomer stirena tidak dapat langsung berinteraksi dengan molekul karet alam (Kawahara \& Chaikumpollert, 2012). Selain itu protein juga bertindak sebagai radical scavenger yang dapat menurunkan reaktivitas radikal bebas yang dibentuk oleh inisiator pada tahap inisiasi dan propagasi selama kopolimerisasi cangkok berlangsung (Nakason et al., 2006). Bahkan keberadaan protein dapat menterminasi dekomposisi inisiator dalam menghasilkan radikal bebas (Kreua-ongarjnukool et al., 2012).

b. Sistem reaksi kopolimerisasi cangkok emulsi tidak dikondisikan pada atmosfer inert sehingga udara bebas yang mengadung $\mathrm{O}_{2}$ dapat mempenetrasi ke dalam campuran lateks karet alam dan monomer stirena. $\mathrm{O}_{2}$ mengakibatkan radikal bebas menjadi tidak aktif sehingga tidak mampu membentuk monomer radikal dengan optimal.

c. Laju tetesan penambahan monomer stirena dianggap terlampau cepat sehingga radikal monomer stirena cenderung membentuk homopolistirena yang tidak menempel pada rantai molekul karet alam. Stirena termasuk da- lam golongan monomer vinilik yang memiliki reaktivitas tinggi.

Pembentukan TPNR kopoli NR-ST dikonfirmasi berdasarkan hasil analisis spektroskopi FTIR seperti terlihat pada Gambar 2. Pada Gambar 2 terlihat terdapat perbedaan beberapa puncak pita serapan antara spektra lateks karet alam pekat (a) dengan spektra kopoli NR-ST (b). Karakteristik karet alam dapat dilihat dari pita serapan pada bilangan gelombang 1660 $\mathrm{cm}^{-1}$ merupakan vibrasi ulur gugus $\mathrm{C}=\mathrm{C}, 2960$ dan $1446 \mathrm{~cm}^{-1}$ untuk vibrasi ulur dan tekuk gugus metil $\left(\mathrm{CH}_{3}\right)$ serta 2852 dan $1375 \mathrm{~cm}^{-1}$ untuk vibrasi ulur dan tekuk gugus metilen $\left(\mathrm{CH}_{2}\right)$. Selanjutnya pada spektra kopoli NR-ST meskipun memiliki pola yang mirip dengan spektra karet alam namun menunjukkan kemunculan puncak yang tajam pada pita serapan baru antara lain pada bilangan gelombang $696 \mathrm{~cm}^{-1}$ untuk vibrasi tekuk ikatan $\mathrm{CH}$ pada rantai cincin benzena, $1493 \mathrm{~cm}^{-1}$ untuk vibrasi ulur ikatan $\mathrm{C}=\mathrm{C}$ pada rantai cincin benzena, dan $1600 \mathrm{~cm}^{-1}$ untuk vibrasi ulur cincin benzena pada molekul stirena. Kemunculan ketiga pita serapan baru tersebut diikuti oleh penurunan intensitas serapan pada bilangan gelombang 1660 $\mathrm{cm}^{-1}$ akibat dari pemutusan ikatan rangkap $\mathrm{C}=\mathrm{C}$ pada rantai molekul karet alam yang digantikan

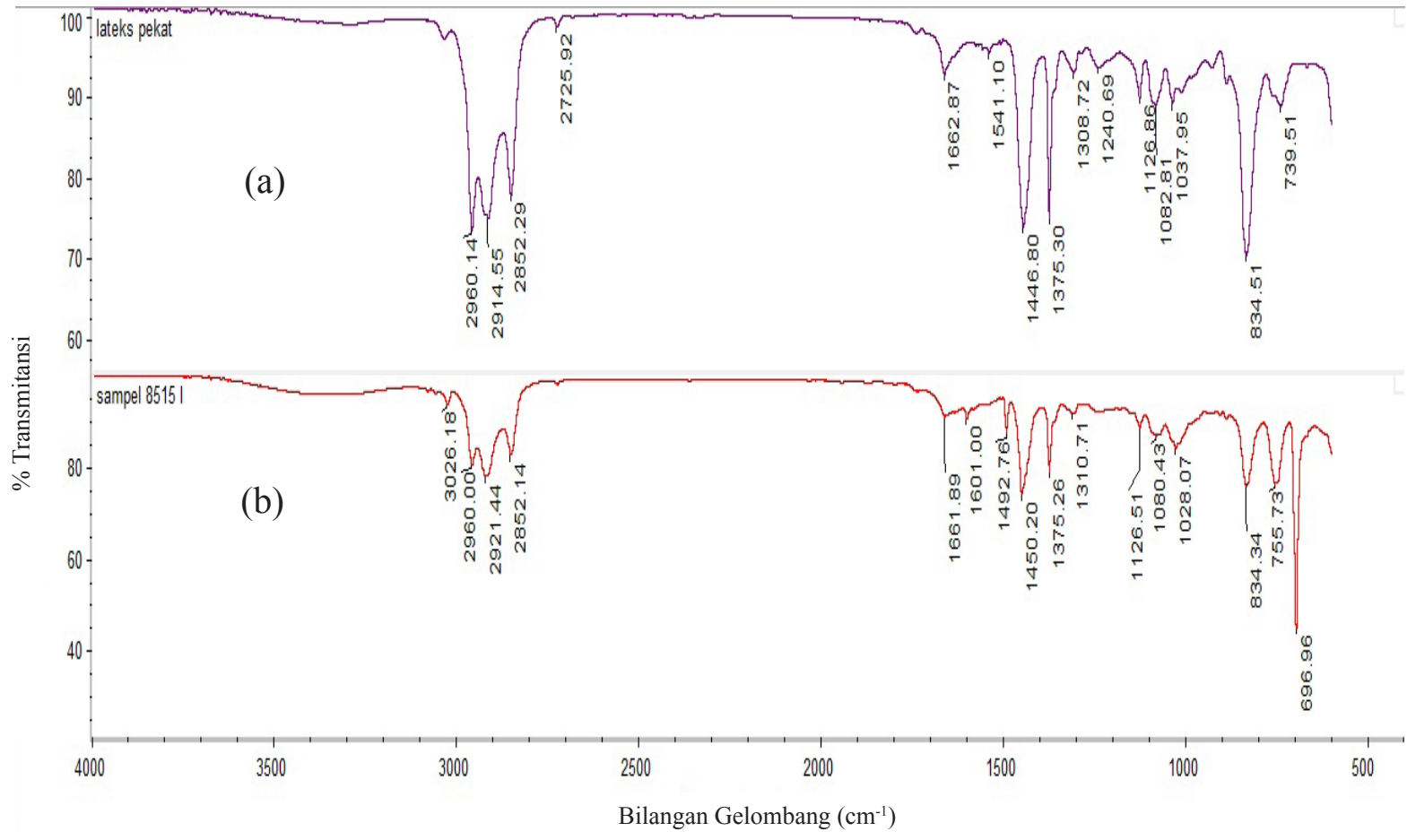

Gambar 2. Spektrum FTIR (a) karet alam dan (b) kopoli NR-ST. 
oleh pembentukan percabangan monomer stirena secara adisi.

\section{Kopoli NR-ST sebagai Aditif Peningkat Indeks Viskositas Minyak Pelumas}

Standar mutu dan pengujian minyak pelumas kendaraan bermotor yang dioperasikan di Indonesia dikeluarkan oleh Direktorat Jendral Minyak dan Gas berdasarkan Surat Keputusan Ditjen Migas Nomor 85K/34/DDJM/1998 menetapkan viskositas sebagai parameter utama disamping beberapa parameter lain seperti titik nyala, angka basa total, kandungan abu sulfat, kandungan logam $(\mathrm{Ca}$, $\mathrm{Mg}, \mathrm{Zn}$ ), stabilitas pembusaan, kadar bahan bakar dan kadar air. Bahkan oleh Society of Automotive Engineers (SAE) parameter viskositas digunakan sebagai dasar penggolongan minyak pelumas komersial. Aturan tersebut mempersyaratkan nilai viskositas minyak pelumas sesuai SAE dan nilai indeks viskositas minimal 90. Dalam penelitian ini, mutu minyak pelumas baru yang diproduksi dengan penambahan TPNR atau kopoli NR-ST dalam minyak pelumas dasar HVI pada berbagai konsentrasi sebagai peningkat indeks viskositas ditentukan hanya didasarkan pada hasil pengujian parameter indeks viskositas, viskositas kinematik pada suhu 40 dan $100^{\circ} \mathrm{C}$, densitas pada suhu ruang, kadar magnesium, dan kadar abu.

Penambahan kopoli NR-ST turut mengubah visualisasi fisik minyak pelumas yang dibentuk. Visualisasi fisik meskipun tidak termasuk dalam syarat standar mutu, namun dapat digunakan sebagai indikator awal dalam penilaian mutu minyak pelumas. Seperti tampak pada Gambar 3, minyak lumas dasar golongan parafinik, HVI 60 berwarna kuning jernih dan HVI 650 berwarna coklat jernih. Keberadaan kopoli NRST yang terlarut dalam minyak pelumas dasar mengakibatkan warnanya berubah menjadi semakin keruh dengan bertambahnya konsentrasi kopoli NR-ST karena kandungan total padatan dalam minyak pelumas yang semakin tinggi dan meningkatnya viskositas minyak lumas (Pillon, 2011). Kandungan fraksi berat dalam komponen penyusun HVI 650 menyebabkan HVI 650 memiliki warna lebih gelap daripada HVI 60.

Penambahan karet alam termoplastik kopoli NR-ST berbobot molekul tinggi ke dalam minyak lumas dasar turut menyebabkan peningkatan densitas minyak pelumas seperti terlihat pada Gambar 4 (Rudnick, 2013). Karet alam termoplastik kopoli NR-ST ketika dicampurkan ke dalam minyak lumas dasar mengakibatkan kerapatan molekul-molekul senyawa yang terdistribusi dalam minyak pelumas tersebut meningkat sehingga densitas minyak pelumas bertambah meskipun tidak terlalu signifikan. Pada dosis kopoli NR-ST yang sama, minyak pelumas yang dibuat dari minyak lumas dasar HVI 650 memiliki densitas lebih tinggi daripada HVI 60 akibat kandungan fraksi berat dalam HVI 650 yang lebih besar daripada dalam HVI 60.

Nilai viskositas kinematik sangat bergantung pada nilai specific gravity dari minyak pelumas. Kedua parameter memiliki hubungan yang saling berkebalikan yang dinyatakan dengan peningkatan

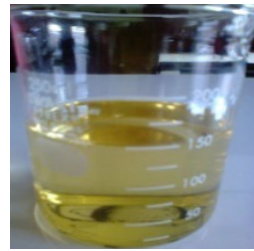

a

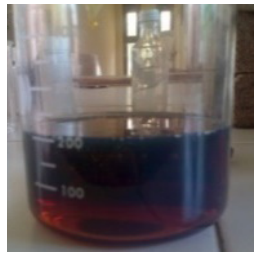

e

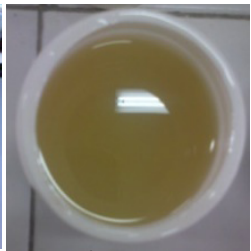

b

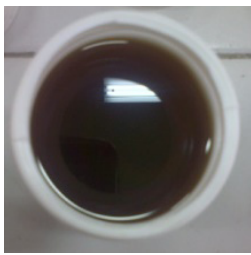

f

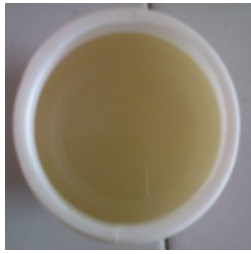

C

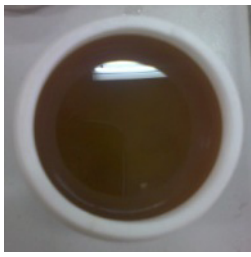

g

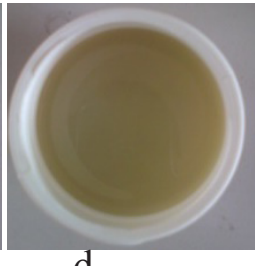

d

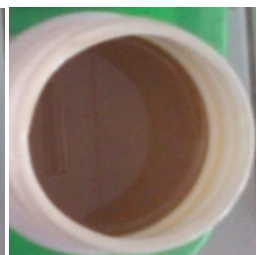

$\mathrm{h}$

Gambar 3. Perubahan warna minyak pelumas sebelum dan setelah penambahan aditif (a) HVI 60 murni (b) HVI $60+1 \%$ kopoli NR-ST, (c) HVI $60+3 \%$ kopoli NR-ST, (d) HVI $60+5 \%$ kopoli NR-ST, (e) HVI 650 murni, (f) HVI $650+1 \%$ kopoli NR-ST, (g) HVI $650+3 \%$ kopoli NR-ST, (h) HVI $650+5 \%$ kopoli NR-ST. 


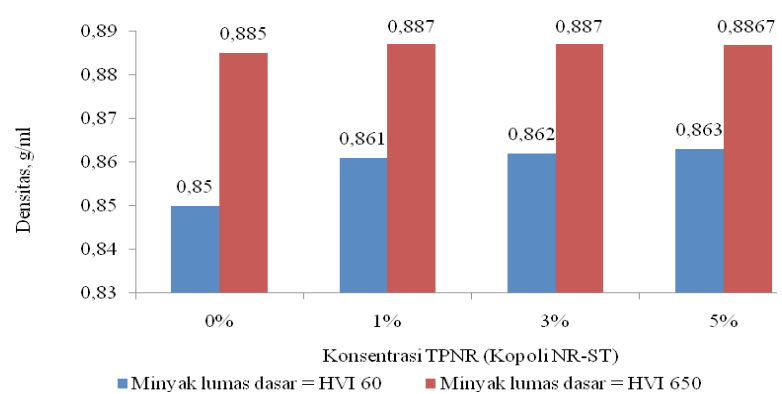

Gambar 4. Densitas minyak pelumas.

densitas minyak pelumas akibat penambahan karet alam termoplastik akan diikuti oleh penurunan viskositas kinematik namun viskositas dinamik yang semakin tinggi. Perhitungan viskositas kinematik minyak pelumas ditunjukkan pada Gambar 5 dan 6. Kerapatan massa yang besar mengakibatkan molekul-molekul senyawa yang terdispersi dalam minyak pelumas sukar bergerak atau memiliki daya alir yang rendah ditunjukkan oleh berkurangnya nilai viskositas kinematik dengan bertambahnya konsentrasi karet alam termoplastik. Penyimpangan nilai viskositas kinematik terjadi pada suhu pengujian $100^{\circ} \mathrm{C}$ untuk HVI 60 yang ditambah kopoli NR-ST berbagai konsentrasi dan HVI 650 yang dicampur dengan $1 \%$ kopoli NR-ST. Selanjutnya pada konsentrasi penambahan karet alam termoplastik untuk jenis HVI yang sama namun pada suhu yang berbeda terlihat bahwa viskositas kinematik minyak pelumas pada suhu $40^{\circ} \mathrm{C}$ lebih tinggi daripada $100^{\circ} \mathrm{C}$ yang disebabkan karena pada suhu tinggi, gaya kohesi atau gaya ikat antar molekul dalam minyak lumas semakin berkurang sehingga minyak lumas dapat mengalir lebih lancar (Iskandar dkk., 2001).

Minyak lumas dasar HVI-60 dan HVI-650 memiliki indeks viskositas sebesar 100 dan 92 , nilai ini telah memenuhi standar yang mempersyaratkan indeks viskositas minyak pelumas di atas 90 . Namun nilai indeks viskositas tersebut perlu tetap ditingkatkan untuk memperbaiki ketahanan viskositas minyak pelumas terhadap perubahan suhu. Minyak pelumas dengan nilai indeks viskositas tinggi akibat penambahan TPNR (kopoli NR-ST) berarti bahwa molekul-molekul kopoli NR-ST yang telah terlarut dan terdistribusi dalam minyak pelumas dasar memberikan pengaruh kestabilan panas minyak lumas yang semakin baik, minyak pelumas tidak mengental pada suhu rendah dan tidak menjadi encer maupun terdekomposisi pada suhu tinggi. Molekul stirena

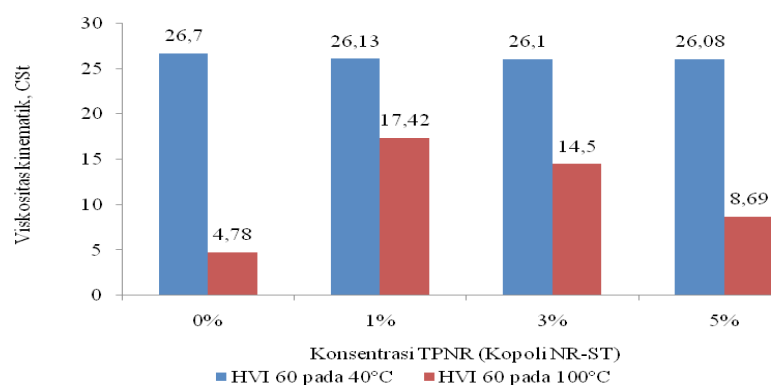

Gambar 5. Viskositas kinematik minyak pelumas pada suhu 40 dan $100^{\circ} \mathrm{C}$ (HVI 60).

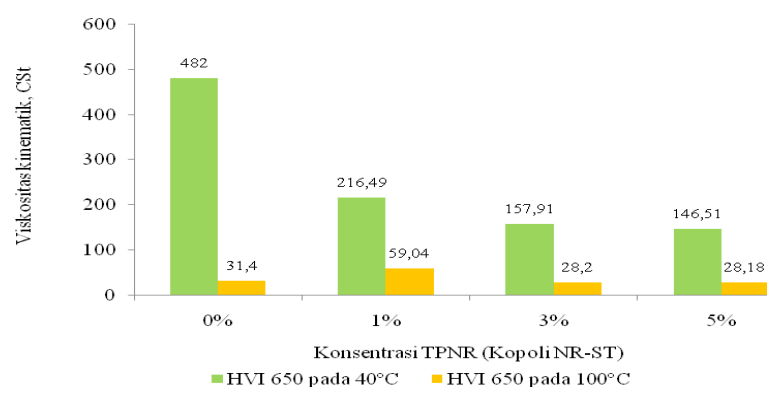

Gambar 6. Viskositas kinematik minyak pelumas pada suhu 40 dan $100^{\circ} \mathrm{C}$ (HVI 650).

yang berikatan dengan karet alam dalam molekul kopoli NR-ST memiliki kestabilan panas yang baik disebabkan karena ikatan rangkap $\mathrm{C}=\mathrm{C}$ dalam cincin benzena penyusun molekul stirena saling berresonansi satu dengan yang lain. Resonansi tersebut menyebabkan senyawa stirena memiliki ketahanan panas dan kimiawi yang baik. Berdasarkan Gambar 7 diketahui bahwa setelah penambahan kopoli NR-ST sebesar 1\%, 3\%, dan $5 \%$ maka indeks viskositas minyak pelumas meningkat berturut-turut menjadi sebesar 181, 185,186 untuk minyak lumas dasar jenis HVI 60 (naik sekitar $80 \%$ dari nilai awal sebesar 100) dan $141,143,145$ untuk minyak lumas dasar jenis HVI 650 (naik sekitar 50\% dari nilai awal sebesar 92).

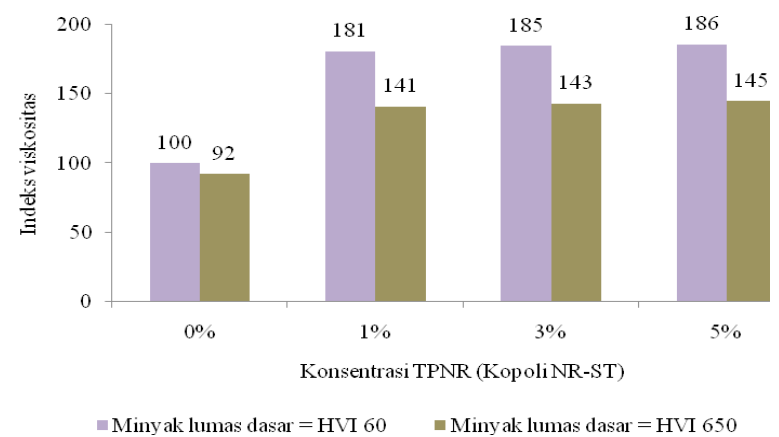

Gambar 7. Indeks viskositas minyak pelumas. 
Tabel 2. Sifat kimia minyak pelumas.

\begin{tabular}{ccccc}
\hline \multirow{2}{*}{$\begin{array}{c}\text { Minyak lumas } \\
\text { dasar }\end{array}$} & $\begin{array}{c}\text { Dosis kopoli } \\
\text { NR-ST }\end{array}$ & Kadar abu, $\%$ & Kadar logam Mg, $\%$ & $\mathrm{pH}$ \\
\cline { 3 - 5 } HVI-60 & $1 \%$ & 0,00979 & 0,003517 & 5 \\
HVI-60 & $3 \%$ & 0,01477 & 0,003362 & 5 \\
HVI-60 & $5 \%$ & 0,01468 & 0,003496 & 5 \\
HVI-650 & $1 \%$ & 0,00986 & 0,004375 & 5 \\
HVI-650 & $3 \%$ & 0,00960 & 0,003159 & 5 \\
HVI-650 & $5 \%$ & 0,00965 & 0,002891 & 5 \\
\hline
\end{tabular}

Minyak pelumas baru dari pencampuran TPNR kopoli NR-ST dengan HVI 60 berbagai dosis dan HVI 650 hanya pada dosis 5\% memiliki nilai indeks viskositas yang dapat bersaing dengan minyak pelumas komersial yang menurut SAE tipe 20W-50, 10W-40 dan 15W-40 secara berurutan sebesar 128, 144, dan 135. Minyak pelumas komersial ini yang telah teruji dapat bersirkulasi pada suhu rendah dan memberi perlindungan optimal terhadap keausan komponen mesin pada suhu dan kecepatan tinggi. Standardisasi minyak pelumas di dunia pertama kali dilakukan oleh Society of Automotive Engineers (SAE) dengan aturan SAEJ 300. Dalam peraturan tersebut terdapat kode yang menggambarkan tingkat viskositas minyak pelumas, misal $20 \mathrm{~W}-50$ berarti minyak pelumas memiliki tingkat viskositas sama dengan SAE pada suhu udara musim dingin dan SAE 50 pada suhu udara musim panas (Nugroho \& Sunarno, 2012).

Sifat kimia minyak pelumas turut diperhitungkan sebagai faktor pendukung dalam menentukan mutu minyak pelumas baru. Tabel 2 merangkum sifat kimia minyak pelumas baru yang terdiri atas parameter kadar $\mathrm{Mg}$, kadar abu, dan $\mathrm{pH}$.

Kadar abu minyak pelumas cukup rendah yang menandakan kandungan logam anorganik serta senyawa aspalten dalam minyak lumas yang sangat rendah. Begitu pula dengan parameter kadar logam Mg. Hasil pengujian kedua parameter ini mengindikasikan bahwa kadar bahan pengotor yang rendah sehingga minyak pelumas dapat berfungsi optimal karena mesin tidak cepat aus, tidak mengganggu aliran minyak pelumas diantara mesin yang sedang beroperasi karena pengotor yang terakumulasi dapat menimbulkan kerak yang dapat menyumbat mesin atau menghambat pertukaran panas antar mesin. Penambahan TPNR pasti turut menaikkan kadar abu dan logam minyak pelumas baru karena di dalam karet alam termoplastik tersebut telah menangandung abu dan berbagai logam anorganik. Minyak pelumas diharapkan tidak bersifat asam karena sifat asam menunjukkan bahwa dalam minyak pelumas tersebut terdapat bahan pengotor yang dapat memicu terjadinya korosi seperti komponen sulfur tertentu (merkaptan). Hasil pengujian $\mathrm{pH}$ minyak pelumas diperoleh nilai sebesar 5 atau bersifat asam lemah.

\section{KESIMPULAN}

Karet alam termoplastik, kopoli (NR-ST) yang disintesis dari 85 bagian karet alam dan 15 bagian monomer stirena secara kopolimerisasi cangkok emulsi yang memiliki efisiensi kopolimerisasi cangkok sebesar $56,48 \%$ dapat berfungsi dengan baik sebagai aditifjenis peningkat indeks viskositas minyak pelumas pada saat ditambahkan dalam minyak lumas dasar golongan parafinik yaitu HVI 60 dan HVI 650 terutama pada dosis 5\%. Minyak pelumas baru yang diperoleh memiliki indeks viskositas tinggi di atas indeks viskositas minyak lumas dasar sebesar 186 untuk HVI 60 dan 145 untuk HVI 650, sehingga memenuhi persyaratan standar sesuai Surat Keputusan Ditjen Migas Nomor 85K/34/DDJM/1998, dan dapat bersaing dengan minyak pelumas komersial tipe $20 \mathrm{~W}-50$, $10 \mathrm{~W}-40$ dan $15 \mathrm{~W}-40$.

\section{UCAPAN TERIMA KASIH}

Penulis mengucapkan terima kasih dan memberikan penghargaan setinggi-tingginya kepada Pusat Penelitian Karet atas dukungan finansial kepada kegiatan penelitian ini melalui Program InHouse Research Tahun Anggaran 2013.

\section{DAFTAR PUSTAKA}

Abdel-Azim, A., \& Abdel-Aziem, R. M. (2001). Polymeric additive for improving the flow properties and viscosity index of lubricating oils. 
Journal of Polymer Research, 8(2), 111-118, http://dx.doi.org/10.1007/s10965-006-0140-x

Adriany, R., \& Yuliarita, E. (2009). Pemanfaatan lateks karet alam dan beberapa senyawa kopolimer olefin untuk aditif peningkat indeks viskositas minyak lumas otomotif. Prosiding Seminar Nasional Dasar Bahan Bakar 2009, C37-C40.

Ahmed, N. S., \& Nassar, A. M. (2011). Lubricating Oil Additives, Tribology-Lubricants and Lubrication. Kuo, C. H. (Eds.). INTECH Open Access Publisher.

Almeida, A. P. P., de Oliveira, A. P. L. R., Erbetta, C. D. C., de Sousa, R. G., Freitas, R. F. D. S., \& e Silva, M. E. S. R. (2014). Rheological study of polymers used as viscosity index improvers for automotive lubricant oils. Journal of Modern Physics, 5(12), 1085-1093,

http://dx.doi.org/10.4236/jmp.2014.512110

Arayapranee, W., Prasassarakich, P., \& Rempel, G. L. (2002). Synthesis of graft copolymers from natural rubber using cumene hydroperoxide redox initiator. Journal of Applied Polymer Science, 83(14), 2993-3001, http://dx.doi.org/10.1002/app.2328

BPS (Badan Pusat Statistik). (2016). Perkembangan jumlah kendaraan bermotor menurut jenis tahun 1987-2013. Jakarta, Indonesia: BPS.

Covitch, M. J., \& Trickett, K. J. (2015). How polymers behave as viscosity index improvers in lubricating oils. Advances in Chemical Engineering and Science, 5(2), 134-151, http://dx.doi.org/10.4236/aces.2015.52015

Effendi, M. S., \& Adawiyah, R. (2014). Penurunan nilai kekentalan akibat pengaruh kenaikan temperatur pada beberapa merek minyak pelumas. Jurnal INTEKNA, 14(1), 1-9.

Hinchiranan, N., Lertweerasirikun, W., Poonsawad, W., Rempel, G. L., \& Prasassarakich, P. (2009). Cure characteristic and mechanical properties of hydrogenated natural rubber/natural rubber blends. Journal of Applied Polymer Science, 111(6), 28132821, http://dx.doi.org/10.1002/app.29333

Iskandar, S., Marliyanti, I., \& Karda, M. S. (2001). Studi kopolimerisasi radiasi stirena ke dalam film karet alam (Pengaruh dosis iradiasi dan kadar monomer). Risalah Pertemuan Ilmiah Penelitian dan Pengembangan Aplikasi Isotop dan Radiasi, 95-102.

Jukic, A., Vidovic, E., \& Janovic, Z. (2007). Alkyl methacrylate and styrene terpolymers as lubricating oil viscosity index improvers. Chemistry and Technology of Fuels and Oils, 43(5), 386-394, http://dx.doi.org/10.1007/s10553-007-0068-9

Kawahara, S., \& Chaikumpollert, O. (2012). Nanomatrix structure formed for natural rubber. Gigaku, 1, 1-8.

Kohjiya, S., \& Ikeda, Y. (2014). Chemistry, Manufacture, and Applications of Natural Rubber. Cambridge, UK: Woodhead Publishing.

Kreua-ongarjnukool, N., Pittayavinai, P., \& Tuampoemsab, S. (2012). Grafted deproteinized natural rubber as an impact modifier in styrenemethyl methacrylate copolymer sheet. Journal of Chemistry and Chemical Engineering, 6, 698707.

Man, S. H. C., Hashim, A. S., \& Akil, H. M. (2007). Preparation and characterization of styrene-methyl methacrylate in deproteinized natural rubber latex (SMMADPNR). e-Polymers, 7(1), 919-928.

Man, S. H. C., Hashim, A. S., \& Akil, H. M. (2008). Studies on the curing behaviour and mechanical properties of styrene/methyl methacrylate grafted deproteinized natural rubber latex. Journal of Polymer Research, 15, 357-364, http://dx.doi.org/10.1007/s10965-008-9179-1

Morgan, S., Ye, Z., Subramanian, R., \& Zhu, S. (2010). Higher-molecular-weight hyperbranched polyethylenes containing crosslinking structure as lubricant viscosity-index improvers. Polymer Engineering and Science, 50(5), 911-918, http://dx.doi.org/10.1002/pen.21609

Nakason, C., Pechurai, W., Sahakaro, K.\& Kaesaman,A. (2006). Rheological, thermal, and curing properties of natural rubber-g-poly(methyl methacrylate). Journal of Applied. Polymer Science, 99(4), 16001614, http://dx.doi.org/10.1002/app.22518

Nugroho, S. R., \& Sunarno, H. (2012). Identifikasi fisis viskositas oli mesin kendaraan bermotor terhadap fungsi suhu dengan menggunakan laser helium neon. Jurnal Sains dan Seni, 1-5.

Oliveira, P. C., Guimarães, A., Cavaillé, J. Y., Chazeau, L. Gilbert, R. G., \& Santos, A. M. (2005). Poly(dimethylaminoethyl methacrylate) grafted natural rubber from seeded emulsion polymerization. Polymer, 46(4), 1105-1111, http://dx.doi.org/10.1016/j.polymer.2004.11.048

Pillon, L. Z. (2011). Surface Activity of Petroleum Derived Lubricants. New York, USA: CRC Press.

Puspitasari, S. (2015). Pengembangan material elastomer termoplastik berbasis karet alam terdeproteinisasi dan monomer vinil secara kopolimerisasi cangkok emulsi (Tesis). Universitas Indonesia, Indonesia.

Puspitasari, S., Budianto, E., \& Maspanger, D. R. (2015). Kajian modifikasi kimia secara kopolimerisasi cangkok pada pembuatan karet alam termoplastik. Warta Perkaretan, 34(1), 65-76.

Rudnick, L. R (Eds.). (2013). Synthetics, Mineral Oils, and Bio-based Lubricants: Chemistry and Technology (2nd ed.). New York, USA: CRC Press, http://dx.doi.org/10.1201/b13887

Sakdapipanich, J. T., \& Rojruthai, P. (2012). Molecular structure of natural rubber and its characteristics based on recent evidence. In H. R. Sammour 
(Ed.), Biotechnology-Molecular Studies and Novel Applications for Improved Quality of Human Life. Vienna, Austria: InTech.

Sklepić, V. M., Podobnik, M., \& Bambić, J. (2008). Engine oil viscosity index improver behaviour at extended shear stability test. Goriva i Maziva, 47(2), 118-128.

Songsing, K., Vatanatham, T., \& Hansupalak, N. (2013). Kinetics and mechanism of grafting styrene onto natural rubber in emulsion polymerization using cumene hydroperoxide-tetraethylenepentamine as redox initiator. European Polymer Journal, 49(5), 1007-1016,

http://dx.doi.org/10.1016/j.eurpolymj.2013.01.027

Suhartini, M., \& Rahmawati. (2009). Penambahan lateks karet alam kopolimer radiasi dan peningkatan indeks viskositas minyak pelumas sintetis olahan. Jurnal Sains Materi Indonesia, 11(1), 10-14.

Suhartini, M., \& Rahmawati. (2010). Karakteristik kopolimer lateks karet alam-metil metakrilat dalam minyak lumas dasar mineral. Jurnal Ilmiah Aplikasi Isotop dan Radiasi, 6(2), 147-156.
Suhartini, M., Utama, M., \& Suhardono. (2006). Elastomer termoplastik sebagai aditif peningkat viskositas pelumas mineral. Jurnal Sains Materi Indonesia, 7(3), 91-97.

Wei, F., Yu, H., Zeng, Z., Liu, H., Wang, Q., Wang, J., \& Li, S. (2014). Preparation and structural characterization of hydroxylethyl methacrylate grafted natural rubber latex. Polimeros, 24(3), 283-290, http://dx.doi.org/10.4322/polimeros.2014.068

Yamak, H. B. (2013). Emulsion polymerization: Effects of polymerization variables on the properties of vinyl acetate based emulsion polymers, Polymer Science(2nd ch.,pp. 35-72). INTECHOpenAccess Publisher, http://dx.doi.org/10.5772/51498 
